\title{
Of CO2 Emission Reduction Strategy Research under China's Energy Consumption Structure Changes
}

\author{
Lei Han
}

School of Humanities \& Economic Management China University of Geosciences, Beijing, Haidian District, Beijing, 100083

\begin{abstract}
As the highlight of the effects of global warming, carbon dioxide emissions are being concerned by more and more countries. The development of green economy have a deep impact on China's carbon emission, and the way of carbon emission will change accordingly in the future. This paper puts forward some countermeasures to the carbon emission by analyzing china's carbon dioxide emission reduction under the change of energy structure. The conclusion of this paper is that the carbon emissions will be more concentrated and easier to deal with in the future. Therefore, the carbon emission problem in China is the intensive treatment of carbon emission.
\end{abstract}

Keywords-energy; consumption structure; carbon dioxide; emission reduction strategies

\section{ENERgy STRUCtURE CHANGE AND FUtURE TREND IN CHINA}

\section{A. Current State of China's Energy Structure}

China is one of the most coal-rich countries in the world. Coal is always in an important position in China's energy consumption structure. With the progress of society development and the proven exploitation of oil resources, onetime energy consumption structure has a certain degree of change. However, the proportion of coal resources is still high. In 2016, China's energy structure is: oil is $19 \%$, natural gas is $6.2 \%$, raw coal is $61.8 \%$ and clean energy is $13 \%$. It can be seen that coal consumption still prevails.

\section{B. The Future Trend of China's Energy Structure}

According to the data released by BP world energy statistics yearbook, trend chart of China's coal, oil, natural gas consumption and a total energy consumption is as shown in FIGURE. 1.

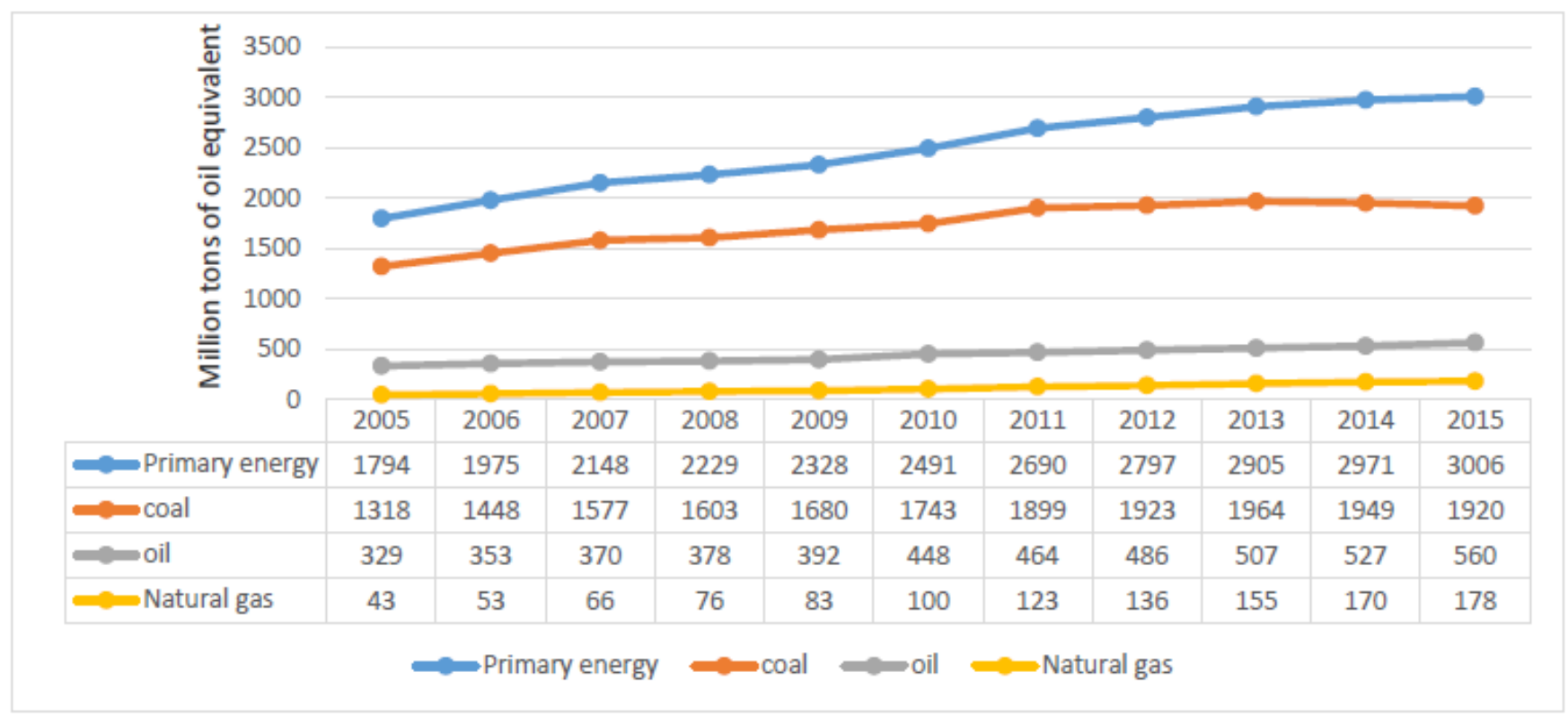

FIGURE I. THE ANNUAL TREND OF COAL, OIL, NATURAL GAS CONSUMPTION AND A TOTAL ENERGY CONSUMPTION

By analysing the data and the trend line from the figure 1, we find that the consumption of coal resources in our country increases year by year between 2005 and 2011, and is pretty stable from 2011 to 2015. In the past years, China's oil and natural gas consumption has been steadily rising. 
In the report of China sustainable energy development strategy research, more than 20 academicians from Chinese Academy of Sciences and Academy of Engineering also agreed that it was not until 2050 that the percentage of energy consumption of coal would not be less than $50 \%$. It can be predicted that the energy consumption structure which is mainly based on coal resources and determined by the energy resource conditions is difficult to change in the short term. The coal resources will still play an irreplaceable role in the process of the whole energy market in decades.

Based on the analysis of the above mentioned and combined with the present situation of our country economy development, we can come to the conclusion that the change of energy consumption structure has the following characteristics in our country in recent years: (1) With the steady development of social economy, China's total primary energy consumption demand is growing; (2)With the enhancement of environmental awareness and energy security policy, natural gas, hydro, wind, solar, nuclear and other clean energy have a rapid development .The proportion of China's clean energy in energy consumption rapidly increases. Clean energy has played an alternative role in coal and oil to some extent; (3) The trend of environmental protection promotes the efficiency of coal in thermal power enterprises. In addition, the efficient use of clean energy has also replaced some coal energy consumption to a certain extent.

\section{II.THE INFLUENCE OF THE CHANGE TREND OF ENERGY CONSUMPTION STRUCTURE ON CHINA'S CARBON DIOXIDE EMISSION REDUCTION}

\section{A. The Current Situation of Carbon Dioxide Emission in China}

China has become the largest $\mathrm{CO} 2$ emitter in the world. According to the report of Tyndall climate change research center, China's CO2 emissions were 9.52 billion to in 2013, 4.2\% more than in 2012, and accounting for $26.4 \%$ of the world's $\mathrm{CO} 2$ emissions. In recent years, the CO2 emission in China is shown in FIGURE. 2.

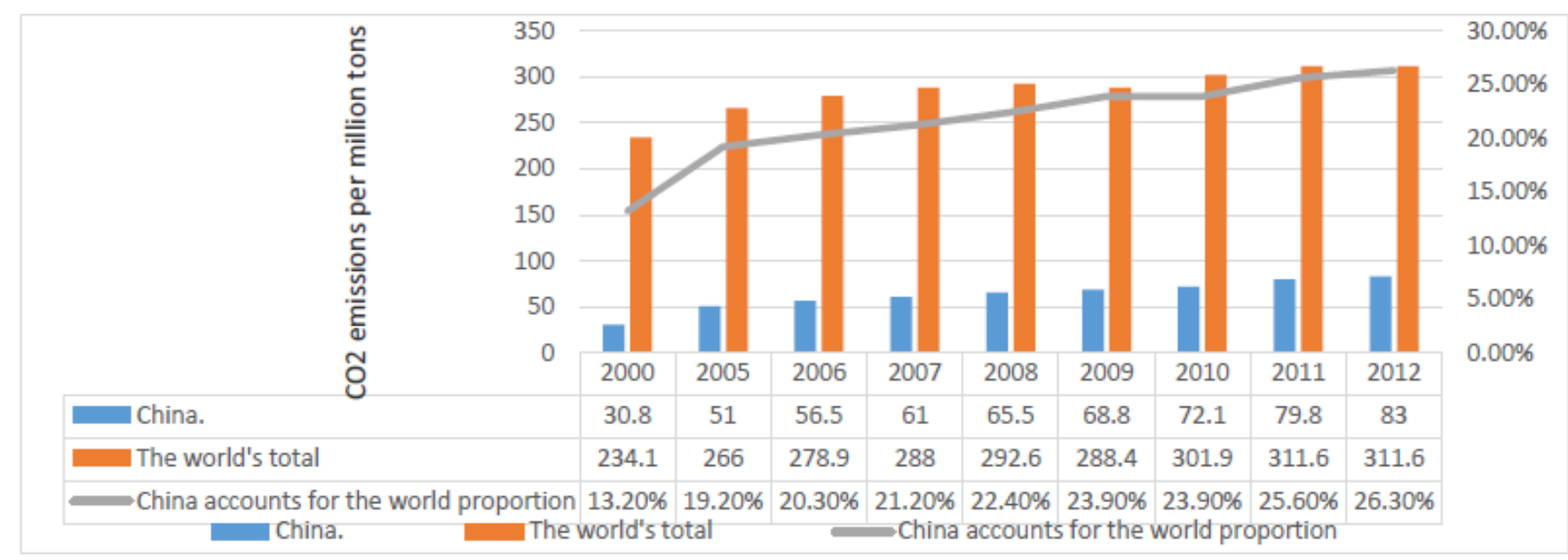

FIGURE II. THE EMISSION OF CO2 IN CHINA IN RECENT YEARS

B. The Energy Consumption of China's Electricity Energy Structure

According to the statistics of China Electricity Council, China's power generation in all types of ways from 2008 to 2016 is shown in FIGURE 3.

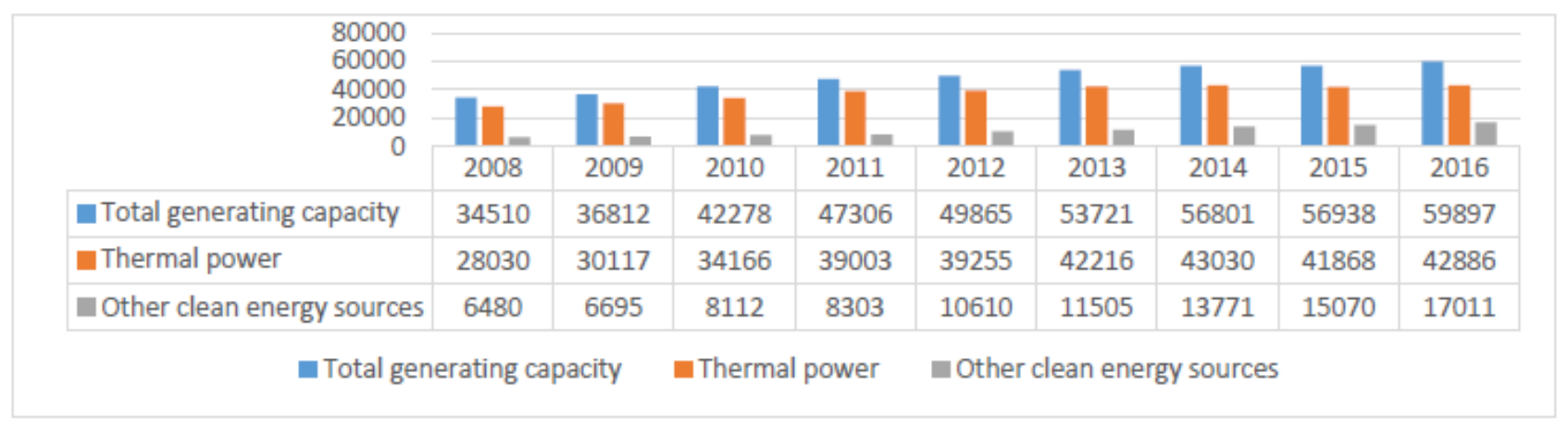

FIGURE III. STATISTICS OF ELECTRICITY GENERATION IN CHINA FROM 2008 TO 2016 (UNIT: 100 MILLION KILOWATT HOUR) 
Through the analysis of the data in FIGURE. 3, it can be found that: (1) With the development of social economy, China's electricity generation is growing rapidly. In 2016, China's total power generation reached 598.97 billion KWH. (2) In recent years, China has been committed to the development of clean energy. So China's hydropower, wind power, nuclear power, solar energy and other clean energy generation capacity can be significantly increased. (3) Although the clean energy power generation is in rapid development, in addition to some fluctuations in 2015, China's thermal power generation is still growing. China's total thermal power reached up to 4.2886 trillion kilowatt hours in 2016. Thermal power is still the most important power generation method in China at present.(4) Changes in energy structure will reduce a small quantities of carbon emissions, but most of the carbon emissions from car exhausts will continue to translate into carbon emissions in coal-fired power generation. This means that carbon emissions will be more concentrated and easier to deal with in the future. Therefore, the carbon emission problem in China is the intensive treatment of carbon emission.

\section{CARBON DIOXIDE EMISSION REDUCTION TECHNOLOGY}

\section{A. Current CO2 Emission Reduction Technology}

Current $\mathrm{CO} 2$ emission reduction technologies include the "carbon-free technology" of source control -- green energy technology; "carbon reduction technology" of process control - technology for energy conservation and emission reduction of fossil energy; The end of the control technology-Dioxide Capture and Storage(Carbon Dioxide Capture and Storage CCS) ${ }^{[3]}$.

At present, it is widely believed that effective implementation of CCS technology can reduce the emissions of large source of $\mathrm{CO} 2$ emissions and achieve $\mathrm{CO} 2$ emission reduction greatly in a relatively short period of time. It can obtain certain economic interests. So it is used as a transitional technology to reduce emissions. Scholars have carried out a lot of research and experiment on CCS, and have also found many problems limiting the development of CCS. Xian Zhang made a research that experts think that CCS development has three important factors including the storage way, capture mode and the mode of transportation from high to low. The storage methods is most concerned about the potential risks. The experiment proved that the $\mathrm{CO} 2$ geological sequestration has many uncertainties and potential risks, including the leakage, the surface for up, induced earthquake, salt water layer destruction ${ }^{[7-9]}$ and so on.

\section{B. The Proposal of New Technologies for Carbon Dioxide Emission Reduction and Technological Development Status}

CO2 Capture and utilization (CCU) is a new concept that is put forward by Heping XIE for CCS economic problems and risk. With low energy consumption and low cost, the CO2 mineralization was made to convert natural minerals and solid waste into high value-added chemical products, taking the $\mathrm{CO} 2$ as a resource.

CO2 mineralization is a $\mathrm{CO} 2$ sequestration method ${ }^{[5]}$ proposed in recent years. It mainly uses widespreaded alkaline earth metal oxides like olivine, serpentine to react with $\mathrm{CO} 2$, converting them into stable carbonate compounds, so as to realize the $\mathrm{CO} 2$ emissions reduction.

Advantages of $\mathrm{CO} 2$ mineralization includes high mineral resources reserves, wide distribution, actual permanent sequestration without monitoring, and with no harm to the environment; moreover, it can produce economic value products so as to realize the recycling use of $\mathrm{CO}^{[6]}$. However, the technology also faces problems such as high operation cost, slow reaction rate, low conversion rate, high energy consumption of ore and storage of solid waste. compared with CCS, this method is relatively safe for permanent storage.

The potash - mineralized CO2 co-producing potash fertilizer was used as an example to study the economic benefits of the utilization of carbon dioxide mineralization:

By using the method of life cycle assessment (LCA), taking potash fertilizer containing $1 \mathrm{t} \mathrm{K2O}$ for production as a function unit, , the carbon emission reduction potential and economic efficiency of two kinds of potassium feldspar - industrial solid waste system mineralized $\mathrm{CO} 2$ co-production processes are compared and evaluated ${ }^{[7]}$ based on the traditional high furnace smelting potassium feldspar to get soluble potassium fertilizer and the co-production of white cement technology as the reference(table 1) 
TABLE I. THE RAW MATERIAL CONSUMPTION OF DIFFERENT PROCESS AND THE AMOUNT OF CO2 MINERALIZATION

\begin{tabular}{|c|c|c|c|}
\hline & $\begin{array}{l}\text { The soluble potassium } \\
\text { fertilizer of potash in blast } \\
\text { furnace and the production of } \\
\text { white cement }\end{array}$ & $\begin{array}{l}\text { Industrial solid waste activated } \\
\text { potassium feldspar -potassium } \\
\text { extraction and mineralized CO2 } \\
\text { combined with potash fertilizer }\end{array}$ & $\begin{array}{l}\text { Gypsum solid waste carbon reduction (potassium } \\
\text { feldspar gypsum - carbon reduction) }\end{array}$ \\
\hline $\begin{array}{c}\text { Consumption } \\
\text { of Potassium } \\
\text { feldspar }\end{array}$ & $11.19 \mathrm{t}$ & $10.83 \mathrm{t}$ & $9.96 \mathrm{t}$ \\
\hline $\begin{array}{l}\text { Consumption of } \\
\text { coal }\end{array}$ & $10.54 t$ & - & $2.75 t$ \\
\hline $\begin{array}{l}\text { Consumption } \\
\text { of Calcareous } \\
\text { limestone }\end{array}$ & $17.77 \mathrm{t}$ & - & - \\
\hline $\begin{array}{l}\text { Consumption } \\
\text { of Cacl2.2H2O }\end{array}$ & 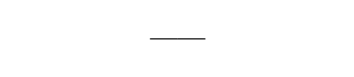 & $7.09 t$ & 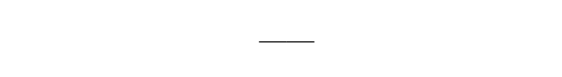 \\
\hline $\begin{array}{l}\text { Consumption of } \\
\text { coal }\end{array}$ & 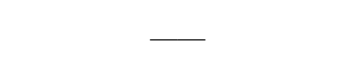 & $1.37 \mathrm{t}$ & $1.99 \mathrm{t}$ \\
\hline $\begin{array}{c}\text { Consumption } \\
\text { of } \\
\text { phosphogypsum }\end{array}$ & - & - & $24.84 \mathrm{t}$ \\
\hline $\begin{array}{l}\text { Mineralization } \\
\text { of CO2 }\end{array}$ & - & $1.11 \mathrm{t}$ & $2.36 \mathrm{t}$ \\
\hline
\end{tabular}

Research shows that whether carbon emissions volume or economic feasibility, Potassium feldspar - industrial solid waste system CO2 mineralization has a great improvement in the process of producing potash fertilizer than the traditional process. Carbon emission reduction potential can reach up to $81.16 \%$ and $20.48 \%$ respectively and the cost can save about $34.75 \%$ and $45.11 \%$ respectively. It also has potash production, carbon emissions and solid waste utilization function. Therefore it has good prospects for industrial application.

\section{ANALYSIS AND FUtURE CENTRALIZATION OF CARBON DIOXIDE EMISSION REDUCTION}

\section{A. Current Situation and Problems of Carbon Dioxide Treatment in China}

At present, the ways of China's carbon emissions mainly rely on the source control, including decentralized technical transformation and energy structure adjustment. Reducing carbon dioxide emissions is mainly achieved by encouraging industrial enterprises to adopt clean energy, production limitation or rebuilding original way of emissions. However, the industrial enterprises as the engine of economic growth, large-scale production limitation obviously does not conform to the practical reality, while the use of clean energy can't meet the energy consumption that the normal operation of enterprises needed. technology upgrade requiring a lot of money, so it is difficult to undertake technical reformation without government subsidies for most of the business. Therefore, the current treatment of carbon dioxide in China cannot meet the demand of emission reduction. The carbon dioxide centralized treatment is needed like sewage treatment.

\section{B. The Analysis of CO2 Intensive Treatment}

According to the prediction of the international energy agency IEA, nearly 20 percent of global emissions reductions will come from end-management technologies, accounting for about 4 billion tons of carbon dioxide per year around the world in the future. The final treatment technologies of carbon dioxide include: carbon capture, sequestration and application technology (CCUS), underground storage technology (CCS), EOR and the mineralized utilization technology and so on. According to the statistics, thermal power accounts for a large proportion in the power energy structure of our country, especially the development of fire still accounting for a large proportion. The electricity consumption of most industrial enterprises is huge. So we can supply power to the enterprises concentrately and make the enterprises focus on power consumption. It can make traditional coal mines to transport coal resources into direct energy delivery throughout the country, which makes $\mathrm{CO} 2$ governance centralized. We will be able to achieve the goal of reducing carbon dioxide emissions by controlling power generation industry's carbon dioxide emissions. Carbon dioxide intensive treatment can also reduce capital investment. The government only needs to upgrade the national thermal power enterprises, and use carbon capture technology in electricity industry to capture $\mathrm{CO} 2$ from the tail gas burning.

\section{V.CONCLUSION}

Emerging energy development impacts on the future energy structure in our country. It makes our country's carbon emission problems more concentrated in the future. China's carbon dioxide emissions will realize the centralized collection, processing likes sewage treatment. So our government needs to strengthen the study of CCS and CCU technologies and use the CCU technology to rebuild original way of emissions in thermal power enterprises in China. Thus, the carbon dioxide can be effectively controlled at the source of emissions. Only in this way can carbon dioxide emission reduction be achieved. 


\section{ACKNOWLEDGEMENT}

The publication of the paper was under the guidance of Professor Wei Cui.

\section{REFERENCES}

[1] Boqiang Lin, Xin Yin, Xiying Liu. Strategic adjustment of China's energy structure under the constraint of energy conservation and carbon emission [J]. China social science, 2010, (01):58-71+222.

[2] white cloud. A brief analysis of the problems of coal consumption and atmospheric environment [J]. China's population, resources and environment, 2016,26(S1):49-52.

[3] Heping Xie. Developing low-carbon technologies and advancing the green economy [J]. China energy, 2010,32(9) : 5-10.

[4] Gang $\mathrm{Xu}$, Longhu Tian,Tong Liu.et al.Strategic analysis of $\mathrm{CO} 2$ mitigation in Chinese power industry[J]. Proceedings of the CSEE, 2011, 31(17) : 1-8.

[5] Heping Xie New concept of CCU for CO2 mineralization [R]. Energy and mining engineering department, academician of Chinese academy of engineering, 2012.

[6] Lackner K S. Carbonate chemistry for sequestering fossil carbon[J] .Annual Review of Energy and the Environment, 2002(27): 193-232.

[7] IPCC.Carbondioxidecaptureandstorage [R].Cambridge: Cambridge Univ Press,2005.

[8] Huihai Liu. Carbon geological sequestration: LBNL's re-search activities[R].Lawrence Berkeley National Laboratory, 2012.

[9] ZobackM D, Gorelick S M. Earthquake triggering and largescale geologic storage of carbon dioxide[J].PNAS,2012,109( 26) : 1016410168. 